\title{
Teacher education programs, field-based practicums, and psychological factors of the implementation of technology by pre-service teachers
}

\author{
Shih-Hsiung Liu \\ National Changhua University of Education, Taiwan
}

\begin{abstract}
This study aimed to validate a second-order structural equation model and to predict the relevance of and relationships among four factors (i.e., teacher education programs, experiences from field-based practicums, psychological factors, and the implementation of technology integration). Each factor consisted of three subfactors, and a questionnaire involving the 12 subfactors was developed and completed by 362 Taiwanese pre-service teachers during internships. Data analysis reveals that the obtained data did not violate univariate normality and multivariate normality assumptions. The measurement instrument exhibited construct validity and discriminant validity. The evaluative results demonstrate an adequate fit to the second-order structural model. Furthermore, teacher education programs and psychological factors exerted a substantially positive influence on the implementation of technology integration, whereas fieldbased experiences exerted only a small effect.
\end{abstract}

\section{Introduction}

Enabling pre-service teachers to integrate technology into instruction is widely considered beneficial. According to Schrum (1999), technology skills-based courses, the integration of technology into methods courses, and a technology-rich field environment are three crucial elements that enable pre-service teachers to implement technology in their teaching. Pre-service teachers can acquire the skills and methods related to technology applications in teacher education programs (Anderson \& Maninger, 2007; Franklin, 2007; Kleiner, Thomas, \& Lewis, 2007) and school-based field practicums (Compton \& Davis, 2010; Doering, Hughes, \& Huffman, 2003; Margaret, Dwight, \& Esther, 2005). Numerous studies have considered the psychological factors that influence pre-service teachers' use of technology, such as beliefs about technology integration (e.g., Sadaf, Newby, \& Ertmer, 2012; Sang, Valcke, van Braak, \& Tondeur, 2010), self-efficacy beliefs concerning technology integration (e.g., Chen, 2010; Lee \& Lee, 2014; Niederhauser \& Perkmen, 2010), and attitudes towards technology-assisted instruction (e.g., Abbitt \& Klett, 2007; Johnston \& Ahtee, 2006). Moreover, Semiz and Ince (2012) evidenced that pre-service teachers' perception of teacher education courses positively influenced their implementation of and self-efficacy beliefs about technology integration. Gibson (2012) indicated that mentor teachers' encouragements and supports also may influence pre-service teachers' willingness to use technology in the classroom. Accordingly, a potential connection is that preservice teachers' implementation of technology integration is influenced by teacher education courses and field-based experiences through a mediation effect of various psychological factors.

We investigated three factors (i.e., teacher education courses, field-based experiences with mentors, and pedagogical beliefs) to build a theoretical model that accounts for pre-service teachers' use of technology in field-based practicums (Liu, 2012). However, factors affecting pre-service teachers' use of technology involve various subfactors. An advanced model involving two-order factors has not yet been completed.

This study tested a second-order structural equation model (SEM) for teacher education programs, fieldbased practicums, psychological factors, and the implementation of technology integration, as well as their subfactors. We also sought to explain the correlation effects of process factors influencing technology use by pre-service teachers during internships.

\section{Literature review}

Effective technology integration requires considering multiple domains of knowledge that support teachers in using technology to teach subject matter (Niess, 2005). The technological, pedagogical, and content knowledge (TPACK) framework, involving a complex interplay among three main types of knowledge - 
content knowledge (CK), pedagogical knowledge (PK), and technological knowledge (TK) - was developed by Mishra and Koehler (2006), and provides a useful theoretical framework for effective use of technology in teaching (Koehler \& Mishra, 2009). Combining the three types of knowledge engenders pedagogical content knowledge (PCK), technological content knowledge (TCK), and technological pedagogical knowledge (TPK). Cox and Graham (2009) claimed that the TPACK concept has inspired teachers, teacher educators, and educational technologists to re-evaluate their TK and classroom application of technology. Certain studies have investigated TPACK to evaluate how pre-service teachers improved integrating technology into teaching (Chai, Koh, Tsai, \& Tan, 2011; Niess, 2005). To examine pre-service teachers' implementation of technology in instruction, three types of TPK, TCK, and technological pedagogical content knowledge (TPCK) that are explicitly related to technology use were considered in this study; PCK that does not involve technology use was excluded when this study collected data on the implementation of technology integration.

\section{Teacher education programs}

Various teacher education courses provide pre-service teachers with subject content knowledge, PK, and TK. According to TPACK, subject content, pedagogy, and technology should be regarded holistically when integrating technology into teaching. However, numerous studies have suggested that teacher education courses do not prepare pre-service teachers to use technology in instructional settings (e.g., Goktas, Yildirim, \& Yildirim, 2008), even if over half of the relevant institutes acknowledge that technology has become mandatory when training pre-service teachers as primary- or secondary-school educators (Moursund \& Bielefeldt, 1999).

Although specific teacher education programs have required pre-service teachers to take an instructional technology course, studies have shown that coursework alone is inadequate to prepare pre-service teachers to use technology in the classroom (Willis \& Sujo de Montes, 2002). A potential reason is that the courses of technology application focus on technology literacy skills, rather than on how to integrate technology into classroom instruction (Llorens, Salanova, \& Grau, 2002; Russell, Bebell, O’Dwyer, \& O’Connor, 2003). A survey of 1,439 American institutions with teacher education programs revealed that $85 \%$ of them offered an educational technology course but frequently focused on learning about different technologies (Kleiner et al., 2007). Specific studies have provided integrated instructional approaches accompanied by a detailed theoretical framework of teacher education courses that can help pre-service teachers advance their TPACK (Finger et al., 2015; Mouza, Karchmer-Klein, Nandakumar, Ozden, \& Hu, 2014; Polly, Mims, Shepherd, \& Inan, 2010). However, Martinovic and Zhang (2012) reported that many teacher education courses are still inadequate and/or lack sufficient modelling of the pedagogical uses of technology. Awotua-Efebo, Olele, and Uche (2014) indicated that course models have been inadequate because of a lack of teacher educators' engaging in course analysis.

Despite a lack of training in integrated courses in teacher education programs, pre-service teachers are willing to use technology during instruction because of updated views, according to which technology is considered a useful and valuable tool for preparing classes (Martinovic \& Zhang, 2012). Thus, theoretically, pre-service teachers' CK, PK, and TK, acquired in teacher education programs, affect their technology integration during internships.

\section{Field-based experiences}

Studies have suggested that teachers' use of technology is influenced by the organisational context (Chen, 2008; Clausen, 2007; Hermans, Tondeur, van Braak, \& Valcke, 2008; Higgins \& Spitulnik, 2008; Lim \& Chai, 2008). Organisational contexts can encompass a wide variety of school-level factors such as leadership, classroom management, physical background, and related relationships. Pre-service teachers might be limited in their ability to become fully involved in the organisational context of school-based field experiences because they participate for only half a year. However, pre-service teachers may have opportunities to experience favourable technology practice with their mentor teachers in school-based field experiences (Doering et al., 2003; Rosaen, Hobson, \& Khan, 2003; Schmid, \& Hegelheimer, 2014). Mentor teachers' modeling of technology use plays a crucial role in how much the technology is used by pre-service teachers (Cuckle, Clarke, \& Jenkins, 2000; Tondeur et al., 2012). Judge and O’Bannon (2007) devised the Project ImPACT (Implementing Partnerships Across the Curriculum with Technology) model regarding field-based technology integration to foster change in technology preparation experiences for pre-service 
teachers. They suggested that the mentor, technology coordinator, and project staff provide mentoring support to interns. Regarding the integration of technology, various school faculty members, instead of the organisational context, are vital factors for pre-service teachers. Al-Ruz and Khasawneh, (2011) revealed that support from teachers and administrators has the highest direct effect on technology integration.

Furthermore, in addition to relationships with mentors and other faculty members, pre-service teachers have opportunities to learn the practical applications of TPACK from peer interns. The questioning of the ideas of a pre-service teacher by a peer fundamentally differs from that peer having their ideas questioned by an experienced mentor teacher (Nokes, Bullough, Egan, Birrell, \& Hansen, 2008). Peer interns' friendships and interactions are conducive to receiving and providing constructive feedback following lessons (Le Cornu \& Ewing, 2008). A potential reason is that collaboration with peers provides pre-service teachers with a lowthreat learning environment that can reduce anxiety and failure avoidance (Angeli \& Valanides, 2009).

Therefore, regarding the implementation of technology integration, pre-service teachers may receive guidance from, and be influenced by, mentors, peer interns, and faculty members, such as other pre-service teachers' mentors and technology coordinators. Consequently, interactions with mentors, peer interns, and faculty members influence the technology integration of pre-service teachers.

\section{Psychological factors}

Teacher beliefs influence their behaviours and are considered an indicator for certain behaviours in class. Beliefs generally refer to suppositions, commitments, and ideologies, whereas knowledge refers to factual propositions and understandings (Calderhead, 1996, p. 715). Concerning beliefs, Ertmer (2005) explained that after gaining knowledge of a proposition, an individual is still free to accept it as being either true or false. Kim, Kim, Lee, Spector, and DeMeester (2013) defined teacher beliefs in relation to technology integration (e.g., a teacher believes that the value of using technology in teaching is high because it promotes the active participation of students and enhances their understanding by using digital resources). Pre-service teachers' beliefs about the value of technology integration in the classroom have been identified as vital predictors of pre-service teachers' intentions to use technology in their practicums (Anderson, Groulx, \& Maninger, 2011). Furthermore, the pedagogical beliefs of pre-service teachers are critical for successfully integrating technology (Ertmer, 1999, 2005; Hermans et al., 2008; Sang et al., 2010; Tondeur, van Keer, van Braak, \& Valcke, 2008).

Self-efficacy involves the perception of one's own competence within a given domain. Self-efficacy beliefs influence decisions and behaviours, and are influenced by individual experiences within a particular domain. Self-efficacy beliefs about the ability to use technology in teaching are considered a factor influencing the decisions that teachers make regarding technology integration in the classroom (Abbitt, 2011).

Based on a definition of attitudes towards behaviour proposed by Fishbein and Ajzen (1975, p. 216), an individual exhibits positive or negative feelings regarding performing certain target behaviour; therefore, this study assumed that a pre-service teacher has either positive or negative feelings towards using technology in teaching. A teacher with a negative attitude might exhibit resistance towards technology in instruction. A teacher's attitude towards technology has been demonstrated in numerous studies to be a crucial factor influencing the implementation of technology integration (e.g., Anderson et al., 2011; Wu, Chang, \& Guo, 2008). Pre-service teachers with a positive attitude towards technology tend to integrate technology successfully in their classroom (Lee \& Lee, 2014). For pre-service teachers, the attitude towards technology integration is a critical factor influencing technology use in teaching (Abbitt \& Klett, 2007; Celik \& Yesilyurt, 2013).

Thus, numerous psychological factors predict a teacher's implementation of technology integration, such as the beliefs about the value of technology integration, the self-efficacy beliefs about the ability to use technology in instruction, and attitudes towards technology integration.

\section{Teacher education programs, field-based experiences, and psychological factors}

Studies have indicated that relationships among teacher education programs, field-based experiences, and psychological factors influence pre-service teachers' use of technology during teaching. For example, Lambert, Gong, and Cuper (2008) showed that pre-service teachers exhibited positive pedagogical beliefs 
about the importance of technology use in education after taking educational technology courses and indicated that educational technology courses prepared pre-service teachers to use technology effectively in instruction. Wang, Ertmer, and Newby (2004) reported that goal setting and vicarious learning experiences, through watching video segments in a teacher education course, substantially affected pre-service teachers' judgments of self-efficacy in technology integration. Furthermore, teacher education programs also influence pre-service teachers' attitudes towards technology integration and lead to a high willingness to use technology in teaching (Martinovic \& Zhang, 2012).

School-based field experiences with technology integration influence pre-service teachers' beliefs about and attitudes towards technology integration. Kajder (2005) demonstrated that mentors' pedagogical beliefs, as perceived by pre-service teachers, markedly influenced pre-service teacher beliefs on technology use during internships. Although few studies have indicated that the beliefs of peer interns and other faculty members regarding pedagogy are associated to those of pre-service teachers, theoretically, pre-service teachers' beliefs about and attitudes towards technology integration may be influenced by interactions with school faculty members. In addition, studies have shown that mentors' positive attitudes towards technology use positively affect the attitudes of pre-service teachers towards the use of technology (Aslan, Zachmeier, Glazewski, \& Ottenbreit-Leftwich, 2012). Thus, school-based field experiences affect pre-service teachers' attitudes towards both technology integration and further technology integration.

Yusop (2015) evidenced that pre-service teachers' beliefs and attitudes towards technology use are crucial determinants of the success of technology integration in their classrooms and suggested that teacher educator programs nurture pre-service teachers' familiarity and intentions to use technology. In other words, teacher education programs and school-based field experiences might both directly and indirectly influence preservice teachers' implementation of technology integration through the mentioned psychological factors.

\section{Methodology}

\section{Research design}

In this study, we tested a second-order SEM to predict the relevance of and relationships among four categories (i.e., teacher education program [PROG], field-based practicum [FIELD], psychological factors [PSYCHO], and implementation of technology integration [IMPLE]) for Taiwanese pre-service teachers during internships. A second-order factor model was established to model the relationships in each factor and their three subfactors, including PROG (i.e., TK, PK, and CK), FIELD (i.e., mentors, peers, and faculty members), PSYCHO (i.e., beliefs about, self-efficacy beliefs concerning, and attitudes towards technology integration), and IMPLE (i.e., TCK, TPK, and TPCK), based on literature review. A survey was conducted for data collection. The SEM model includes measurement and path models. The measurement model was a conventional confirmatory factor model, which was used to assess data validity, whereas the path model consists of the direct, mediated, and total effects of one second-order latent variable on another. The sum of the direct and mediated effects is the total effect (Bollen, 1989).

\section{Research participants}

Based on statistical data obtained from the Taiwan Ministry of Education (2013), approximately 3,900 preservice teachers participate annually in school-based field practicums in secondary schools across Taiwan. According to Cohen, Manion, and Morrison (2007), over 350 pre-service teachers constitute an adequate sample size for achieving a 0.95 confidence level and 5\% confidence intervals. The subjects comprised 410 pre-service teachers who participated in field-based practicums between August 2013 and January 2014. These pre-service teachers were chosen randomly from three main teacher education universities with secondary teacher education institutes in Taiwan, and were asked to participate in the survey conducted from January 2014 to March of 2014. We collected 398 questionnaires, of which 362 questionnaires were valid.

The subjects consisted of 118 male (32.6\%) and 244 female (67.4\%) teachers who had graduated from teacher education universities with majors in mathematics (10.2\%), literacy and language arts (19.6\%), sciences $(16.9 \%)$, social studies $(10.2 \%)$, arts and physical education (11.6\%), vocational professions (10.5\%), integrative activities (8.3\%), and special education (12.7\%).

Before participating in field-based practicums, Taiwanese pre-service teachers must major in a teaching field and complete at least 26 credits in education courses, and be enrolled in at least three courses related to 
instructional methods and technology. In addition, the "Subject/Field-Specific Teaching Method" course is required. The pre-service teachers were required to design lessons and practise teaching according to their mentors' guidance during field-based practicums. Because most of the classrooms in practicum schools were equipped with technological devices such as overhead projectors, the pre-service teachers could implement technology integration lessons during field-based practicums.

\section{Instrument}

We developed a questionnaire to identify the factors that relate to technology integration by pre-service teachers in the practicum context. The questionnaire consisted of four categories, of which each category consisted of three subfactors. Each subfactor consisted of two items. The original items were developed in Chinese; the items were subsequently translated into English for submission.

In the category of teacher education programs, five pre-service teachers participating in field-based practicums were interviewed in December 2013 to collect data regarding the perceptions of acquired knowledge that can enable them to integrate technology in instruction, and to determine how they can acquire various knowledge bases regarding technology integration in teacher education courses. The items were developed based on the interview data. In the category of field-based practicum experiences, the items were developed with a focus on pre-service teachers' interactions with mentors, peers, and other faculty members regarding technology use. The items of the third category, addressing pre-service teachers' psychological factors, were developed according to the definitions of beliefs about, self-efficacy beliefs concerning, and attitudes towards technology integration based on the literature. The fourth category, implementation of technology integration, was based on a TPACK questionnaire from Schmidt et al. (2009).

The responses to each item were scored on a 5-point Likert scale ranging from 1 (strongly disagree) to 5 (strongly agree). All items were repeatedly revised by five professors with relevant expertise. Cronbach's alpha was initially calculated to assess the internal consistency and reliability of the 12 subfactors. The alpha values were as follows: TK, 0.770; PK, 0.653; CK, 0.732; “mentor,” 0.795; “peer,” 0.834; “faculty,” 0.724; “beliefs,” 0.673; “self-efficacy beliefs,” 0.661; “attitude,” 0.667; TCK, 0.669; TPK, 0.751; TPCK, 0.799; and the total questionnaire, 0.911. All Cronbach's alpha values were $>0.6$, revealing that the instrument reached internal consistency reliability.

\section{Data analysis}

After data collection, we evaluated homogeneity in the teaching fields of pre-service teachers, multivariate normality, and validity through factor loadings for the measurement model and the entire model. The model fits were also analysed.

We conducted one-way analysis of variance (ANOVA) to determine whether the teaching fields in which the pre-service teachers had majored exerted dissimilar influences on the 12 subfactors. The analytical results reveal insignificant differences in teaching fields $(\mathrm{TK}, \mathrm{F}=1.283, p>.01 ; \mathrm{PK}, \mathrm{F}=0.769, p>.01 ; \mathrm{CK}, \mathrm{F}=$ $1.414, p>.01$; mentor, $F=2.176, p>.01$; peer, $\mathrm{F}=1.222, p>.01$; faculty, $\mathrm{F}=1.399, p>.01$; beliefs, $\mathrm{F}=$ 1.763, $p>.01$; self-efficacy beliefs, $\mathrm{F}=2.635, p>.01$; attitude, $\mathrm{F}=1.840, p>.01$; TCK, $\mathrm{F}=1.958, p>.01$; TPK, $\mathrm{F}=2.571 p>.01$; TPCK, $\mathrm{F}=0.765, p>.01$ ). This eliminated the potential effect of the teaching fields on the 12 subfactors.

\section{Assessment of multivariate normality}

The SEM programs involved conducting maximum likelihood estimation, which is robust for normality violations and provides remedies for nonnormal variables. According to Bollen and Long (1993), when both skewness and kurtosis coefficients have absolute values $<2.0$, univariate normality is achieved. We generated coefficients from -0.815 to -0.187 for skewness and -0.769 to 0.399 for kurtosis (Table 1 ). The data did not violate the univariate normality assumption for each observed variable. According to Bollen (1989), when Mardia's coefficient is less than $p(p+2)$, where $p$ is the number of observed variables, multivariate normality exists. In this study, Mardia's coefficient was 96.208, and $p=24,96.208<24 \times(24+2)=624$; thus, multivariate normality existed. 
Table 1

Descriptive statistics and assessment of normality

\begin{tabular}{|c|c|c|c|c|c|}
\hline Observed variables & Items & Mean & $S D$ & Skew & Kurtosis \\
\hline TK01 & $\begin{array}{l}\text { My technological knowledge from the teacher } \\
\text { education university can enable me to integrate } \\
\text { technology in teaching. }\end{array}$ & 3.93 & .822 & -0.465 & -0.257 \\
\hline TK02 & $\begin{array}{l}\text { My classmates and I in the teacher education courses } \\
\text { can share our experiences of technology integration } \\
\text { with each other. }\end{array}$ & 3.85 & .802 & -0.339 & -0.313 \\
\hline PK01 & $\begin{array}{l}\text { My pedagogical knowledge from the teacher education } \\
\text { university can enable me to integrate technology in } \\
\text { teaching. }\end{array}$ & 4.15 & .736 & -0.502 & -0.227 \\
\hline PK02 & $\begin{array}{l}\text { I can seek opportunities to observe teachers' instruction } \\
\text { (including the use of video) for promoting my own } \\
\text { instructional skills during learning in the teacher } \\
\text { education courses. }\end{array}$ & 4.28 & .791 & -0.786 & -0.255 \\
\hline CK01 & $\begin{array}{l}\text { My subject content knowledge from the teacher } \\
\text { education university can enable me to integrate } \\
\text { technology in teaching. }\end{array}$ & 4.10 & .779 & -0.637 & 0.266 \\
\hline CK02 & $\begin{array}{l}\text { I can discuss subject content knowledge with my } \\
\text { classmates in the teacher education courses. }\end{array}$ & 4.07 & .849 & -0.778 & 0.399 \\
\hline mentor01 & $\begin{array}{l}\text { My mentor encourages me to use technology in } \\
\text { internships. }\end{array}$ & 3.49 & 1.035 & -0.241 & -0.523 \\
\hline mentor02 & $\begin{array}{l}\text { I can ask my mentor for advice on using technology in } \\
\text { practicing teaching. }\end{array}$ & 3.50 & 1.010 & -0.371 & -0.187 \\
\hline peer01 & $\begin{array}{l}\text { I can ask peer interns for advice on using technology in } \\
\text { practicing teaching. }\end{array}$ & 3.85 & .998 & -0.793 & 0.22 \\
\hline peer02 & $\begin{array}{l}\text { My peer interns and I can share our experiences of } \\
\text { technology integration with each other. }\end{array}$ & 3.88 & .979 & -0.772 & 0.176 \\
\hline faculty01 & $\begin{array}{l}\text { I can receive guidance from school faculty members } \\
\text { when I intend to implement technology integration. }\end{array}$ & 3.45 & .952 & -0.187 & -0.408 \\
\hline faculty02 & $\begin{array}{l}\text { I can receive support from school faculty members } \\
\text { when I integrate technology. }\end{array}$ & 3.70 & .844 & -0.228 & -0.394 \\
\hline belief01 & $\begin{array}{l}\text { I believe that teaching with technology is more } \\
\text { effective than traditional teaching. }\end{array}$ & 3.92 & .845 & -0.470 & 0.037 \\
\hline belief02 & $\begin{array}{l}\text { I believe that technology is critical for enhancing } \\
\text { student learning. }\end{array}$ & 4.22 & .786 & -0.707 & -0.153 \\
\hline $\begin{array}{l}\text { self- } \\
\text { efficacy01 }\end{array}$ & $\begin{array}{l}\text { I believe that I can implement sufficient technology } \\
\text { integration during my practicing teaching. }\end{array}$ & 3.88 & .854 & -0.376 & -0.400 \\
\hline $\begin{array}{l}\text { self- } \\
\text { efficacy02 }\end{array}$ & $\begin{array}{l}\text { I believe that I have sufficient ability to design the } \\
\text { teaching activities by using technology in practicing } \\
\text { teaching. }\end{array}$ & 4.03 & .815 & -0.450 & -0.451 \\
\hline attitude01 & $\begin{array}{l}\text { I think that teachers should have the ability to integrate } \\
\text { technology into teaching. }\end{array}$ & 4.23 & .773 & -0.815 & 0.279 \\
\hline attitude02 & $\begin{array}{l}\text { I think that teachers should spend time to prepare } \\
\text { technology-integration activities. }\end{array}$ & 3.92 & .821 & -0.327 & -0.227 \\
\hline ТCК01 & $\begin{array}{l}\text { I designed digital materials for specific subject contents } \\
\text { during field-based practicums. }\end{array}$ & 3.91 & .879 & -0.307 & -0.769 \\
\hline ТCК02 & $\begin{array}{l}\text { I tried to adjust subject contents for specific } \\
\text { technological tools during field-based practicums. }\end{array}$ & 3.78 & .908 & -0.379 & -0.616 \\
\hline ТРК01 & $\begin{array}{l}\text { I changed my instructional strategies to use specific } \\
\text { technological tools during field-based practicums. }\end{array}$ & 3.99 & .873 & -0.674 & 0.227 \\
\hline ТРК02 & $\begin{array}{l}\text { I used various technological tools for specific } \\
\text { instructional strategies during field-based practicums. }\end{array}$ & 3.97 & .896 & -0.769 & 0.201 \\
\hline ТРСК01 & $\begin{array}{l}\text { I applied the technology that I use in my teaching to } \\
\text { enhance students' learning of specific subject contents } \\
\text { during field-based practicums. }\end{array}$ & 3.96 & .856 & -0.611 & 0.229 \\
\hline ТРСК02 & $\begin{array}{l}\text { I implemented a lesson that appropriately combines } \\
\text { specific subject contents, technological tools, and } \\
\text { instructional strategies during field-based practicums. }\end{array}$ & 3.94 & .821 & -0.483 & -0.079 \\
\hline Mardia’s coefficient & & \multicolumn{2}{|c|}{96.204} & \multicolumn{2}{|c|}{28.163} \\
\hline
\end{tabular}




\section{Validity}

To assess validity, we calculated the standardised regression loading of each observed variable for evaluating construct validity, as well as the average variance extracted (AVE) for identifying discriminant validity, and compared them with correlation coefficients for latent variables.

Each item was loaded significantly on its corresponding first-order factor, according to the standardised factor loadings, which were 0.602-0.869 ( $t$ values, 6.16-14.71, $p<.01$ ), as shown in Table 2. In addition, each first-order was loaded significantly on its higher second-order factor ( $t$ values, 6.29-10.14, $p<.01$ ). According to Hair, Anderson, Tatham, and Black (1998), when the construct validity of latent variables exceeds 0.60 , the measurement instrument exhibits construct validity. The construct validity of each latent variable was $0.667-0.841$ in all first-order latent variables, and that of all second-order latent variables was 0.779-0.966; therefore, > 0.60 (Table 2).

Table 2

Construct and discriminant validity

\begin{tabular}{|c|c|c|c|c|c|c|c|c|c|c|}
\hline \multirow{2}{*}{$\begin{array}{l}\text { Second-order } \\
\text { construct }\end{array}$} & \multirow{2}{*}{$\begin{array}{l}\text { First-order } \\
\text { construct }\end{array}$} & \multirow[t]{2}{*}{ Items } & \multicolumn{4}{|c|}{ First-order factors } & \multicolumn{4}{|c|}{ Second-order factors } \\
\hline & & & Loading & Construct & AVE & $\sqrt{A V E}$ & Loading & Construct & AVE & $\sqrt{A V E}$ \\
\hline \multirow{6}{*}{$\begin{array}{l}\text { PROG, teacher } \\
\text { education } \\
\text { program }\end{array}$} & TK & TK01 & 0.737 & م 78 & 0538 & 0734 & 0664 & \multirow{6}{*}{0.810} & \multirow{6}{*}{0.594} & \multirow{6}{*}{0.771} \\
\hline & in & TK02 & 0.730 & 0.100 & 0.538 & 0.134 & 0.064 & & & \\
\hline & PK & PK01 & 0.813 & 0.672 & 0.512 & 0716 & 0.975 & & & \\
\hline & Pn & PK02 & 0.602 & $0.0 / 2$ & 0.012 & 0.110 & 0.910 & & & \\
\hline & \multirow{2}{*}{ CK } & CK01 & 0.798 & \multirow{2}{*}{0.735} & \multirow{2}{*}{0.581} & \multirow{2}{*}{0.720} & \multirow{2}{*}{0.669} & & & \\
\hline & & CK02 & 0.725 & & & & & & & \\
\hline \multirow{6}{*}{$\begin{array}{l}\text { FIELD, field- } \\
\text { based } \\
\text { experience }\end{array}$} & \multirow{2}{*}{ mentor } & mentor01 & 0.753 & \multirow{2}{*}{0.787} & \multirow{2}{*}{0.650} & \multirow{2}{*}{0.806} & \multirow{2}{*}{0.768} & \multirow{6}{*}{0.779} & \multirow{6}{*}{0.541} & \multirow{6}{*}{0.736} \\
\hline & & mentor02 & 0.856 & & & & & & & \\
\hline & \multirow{2}{*}{ peer } & peer01 & 0.858 & \multirow{2}{*}{0.841} & \multirow{2}{*}{0.726} & \multirow{2}{*}{0.852} & \multirow{2}{*}{0.664} & & & \\
\hline & & peer02 & 0.846 & & & & & & & \\
\hline & \multirow{2}{*}{ faculty } & faculty01 & 0.803 & \multirow{2}{*}{0.721} & \multirow{2}{*}{0.565} & 0752 & 0771 & & & \\
\hline & & faculty02 & 0.697 & & & 0.152 & $0.7 / 1$ & & & \\
\hline & beliefs & belief01 & 0.660 & 0.687 & 0.525 & 0.725 & 0.956 & & & \\
\hline & ventis & belief02 & 0.784 & $0.00 \%$ & $0.0<3$ & 0.123 & 0.350 & & & \\
\hline PS ÝnU, & self-efficacy & efficacy01 & 0.776 & 0.669 & & 0711 & 0994 & 0.966 & 0.904 & 0951 \\
\hline $\begin{array}{l}\text { factors } \\
\text { factilut }\end{array}$ & beliefs & efficacy02 & 0.638 & 0.669 & 0.505 & 0.111 & 0.994 & 0.900 & 0.904 & 0.901 \\
\hline & attitude & attitude01 & 0.672 & 0.669 & 0.503 & 0709 & 0900 & & & \\
\hline & atmiture & attitude02 & 0.745 & 0.005 & 0.005 & 0.705 & 0.300 & & & \\
\hline & TCK & TCK01 & 0.708 & 0.667 & 0.501 & 0.708 & 0.919 & & & \\
\hline IMPLE, & & TCK02 & 0.707 & & & & & & & \\
\hline implementation & TPK & ТРК01 & 0.742 & 0753 & 0604 & 0777 & 0938 & 0.936 & 0.829 & 0910 \\
\hline of technology & IFK & TPК02 & 0.811 & 0.150 & 0.004 & אוד & $0.9<0$ & 0.000 & & 0.010 \\
\hline integration & ТPCK & ТPCK01 & 0.767 & 0.803 & 0.672 & 0.820 & 0.884 & & & \\
\hline
\end{tabular}

${ }^{*} p<.05$

In addition, the AVE of each first-order latent variable exceeded 0.5 (0.503-0.726), and all the square roots of AVE (0.709-0.852) for the 12 subfactors exceeded the correlation coefficients among subfactors (Table 3), demonstrating favourable discriminant validity (Anderson \& Gerbing, 1988). Moreover, in the four second-order latent variables, each AVE for the second-order factor (0.541-0.904) also exceeded 0.5, and the square roots of the AVE (0.736-0.951) were greater than the correlation coefficients among four secondorder constructs (correlation coefficients, 0.397-0.635, $p<.01$ ), consistent with the requirement of discriminant validity. 
Table 3

Correlation coefficients among 12 subfactors

\begin{tabular}{|c|c|c|c|c|c|c|c|c|c|c|c|}
\hline & 1 & 2 & 3 & 4 & 5 & 6 & 7 & 8 & 9 & 10 & 11 \\
\hline TK (1) & 1 & & & & & & & & & & \\
\hline PK (2) & $.429^{* *}$ & & & & & & & & & & \\
\hline CK (3) & $.373^{* *}$ & $.543^{* *}$ & & & & & & & & & \\
\hline Mentor (4) & $.284^{* *}$ & $.252^{* *}$ & $.289^{* *}$ & & & & & & & & \\
\hline Peer (5) & $.371^{* *}$ & $.262^{* *}$ & $.296^{* *}$ & $.375^{* *}$ & & & & & & & \\
\hline Faculty (6) & $.260^{* *}$ & $.223^{* *}$ & $.259^{* *}$ & $.513^{* *}$ & $.354^{* *}$ & & & & & & \\
\hline Beliefs (7) & $.345^{* *}$ & $.317^{* *}$ & $.284^{* *}$ & $.244^{* *}$ & $.306^{* *}$ & $.309^{* *}$ & & & & & \\
\hline Self-efficacy (8) & $.395^{* *}$ & $277^{* *}$ & $.319^{* *}$ & $.246^{* *}$ & $.298^{* *}$ & $.290^{* *}$ & $.627^{* *}$ & & & & \\
\hline Attitude (9) & $.273^{* *}$ & $.227^{* *}$ & $.330^{* *}$ & $.223^{* *}$ & $.238^{* *}$ & $.238^{* *}$ & $.552^{* *}$ & $.626^{* *}$ & & & \\
\hline TCK (10) & $.477^{* *}$ & $.380^{* *}$ & $.333^{* *}$ & $.256^{* *}$ & $.286^{* *}$ & $.219^{* *}$ & $.437^{* *}$ & $.535^{* *}$ & $.388^{* *}$ & & \\
\hline TPK (11) & $.502^{* *}$ & $.316^{* *}$ & $.312^{* *}$ & $.303^{* *}$ & $.372^{* *}$ & $.330^{* *}$ & $.439^{* *}$ & $.577^{* *}$ & $.384^{* *}$ & $.607^{* *}$ & \\
\hline TPCK (12) & $.509^{* *}$ & $.331^{* *}$ & $.382^{* *}$ & $.304^{* *}$ & $.355^{* *}$ & $.328^{* *}$ & $.440^{* *}$ & $.536^{* *}$ & $.472^{* *}$ & $.595^{* *}$ & $.634^{* *}$ \\
\hline
\end{tabular}
${ }^{* *} p<.01$

\section{Evaluation of the entire model}

Structural equation modeling enabled determining the significance of variance in the entire model. In this study, the first-order latent variables in each category were reflective of one second-order latent variable (i.e., PROG, FIELD, PSYCHO, and IMPLE). According to Kline (2005), the suggested $\chi^{2} / d f$ value is $<3(p>.05)$ for large samples. For each second-order factor model, confirming that $\chi^{2} / d f<3, p=.092-.326$, indicating that the value was adequate. Furthermore, according to the suggested guidelines by Bollen (1989), Kline (2005), and Pedhazur (1997), all other values related to model-fit indices were favourable; that is, each second-order factor model exhibited a favourable fit. Table 4 lists the model-fit results.

This study evaluated the entire model of correlations among four second-order latent variables. Table 4 shows that $\chi^{2} / d f=1.149(p=.063>.05)$, indicating that the model exhibited a favourable fit according to the values of model-fit indices. Consequently, the SEM involving the four second-order latent variables, PROG, FIELD, PSYCHO, and IMPLE, was confirmed.

Table 4

Results of model fit indices for the model

\begin{tabular}{lcccccccc}
\hline Model fit indices & $\chi^{2} / d f(p)$ & CFI & GFI & AGFI & NFI & IFI & RMR & RMSEA \\
\hline $\begin{array}{l}\text { Suggested guidelines } \\
\text { Single second-order factor model }\end{array}$ & $<3(p>.05)$ & $\geqq .9$ & $\geqq .9$ & $\geqq .9$ & $\geqq .9$ & $\geqq .9$ & $<.05$ & $<.05$ \\
$\quad$ & & & & & & & & \\
$\quad$ PROG & $1.666(.139)$ & .994 & .992 & .968 & .986 & .994 & .013 & .043 \\
$\quad$ FIELD & $1.813(.092)$ & .994 & .990 & .965 & .986 & .994 & .038 & .047 \\
$\quad$ PSYCHO & $1.656(.174)$ & .997 & .995 & .968 & .994 & .997 & .014 & .043 \\
$\quad$ IMPLE & $1.157(.326)$ & .999 & .993 & .977 & .992 & .999 & .011 & .021 \\
For second-order structural model & $1.149(.063)$ & .991 & .946 & .926 & .935 & .991 & .028 & .020 \\
\hline
\end{tabular}

\section{Path analysis}

Figure 1 shows the path coefficients of the four second-order latent variables. Two of the five path estimates were insignificant, and the remaining ones reached a significant $p$ value $(p<.01)$. All path coefficients were positive. According to Cohen's recommendation, the interpretations of the effect size of correlations are based on standardised path coefficients with absolute values: a small effect $(\leq 0.1)$, moderate effect $(>0.1,<$ $0.5)$, and large effect $(\geq 0.5)$ (Kline, 2005). The total, direct, and indirect effects among the four latent variables were calculated.

Although the direct effects of FIELD on IMPLE and PSYCHO were significant, the effect of FIELD on PSYCHO was 0.203, that of PSYCHO on IMPLE was 0.253, and the indirect effect of FIELD on IMPLE was 0.051 , indicating a small effect.

The standardised effect of PROG on IMPLE was 0.463, that of PROG on PSYCHO was 0.487, that of PSYCHO on IMPLE was 0.253 , and the total effect of PROG on IMPLE was $0.586(0.463+0.487 \times .253$ $=0.586)$, indicating a large effect. 
Finally, the standardised effect of PSYCHO on IMPLE was 0.253 , indicating a moderate effect.

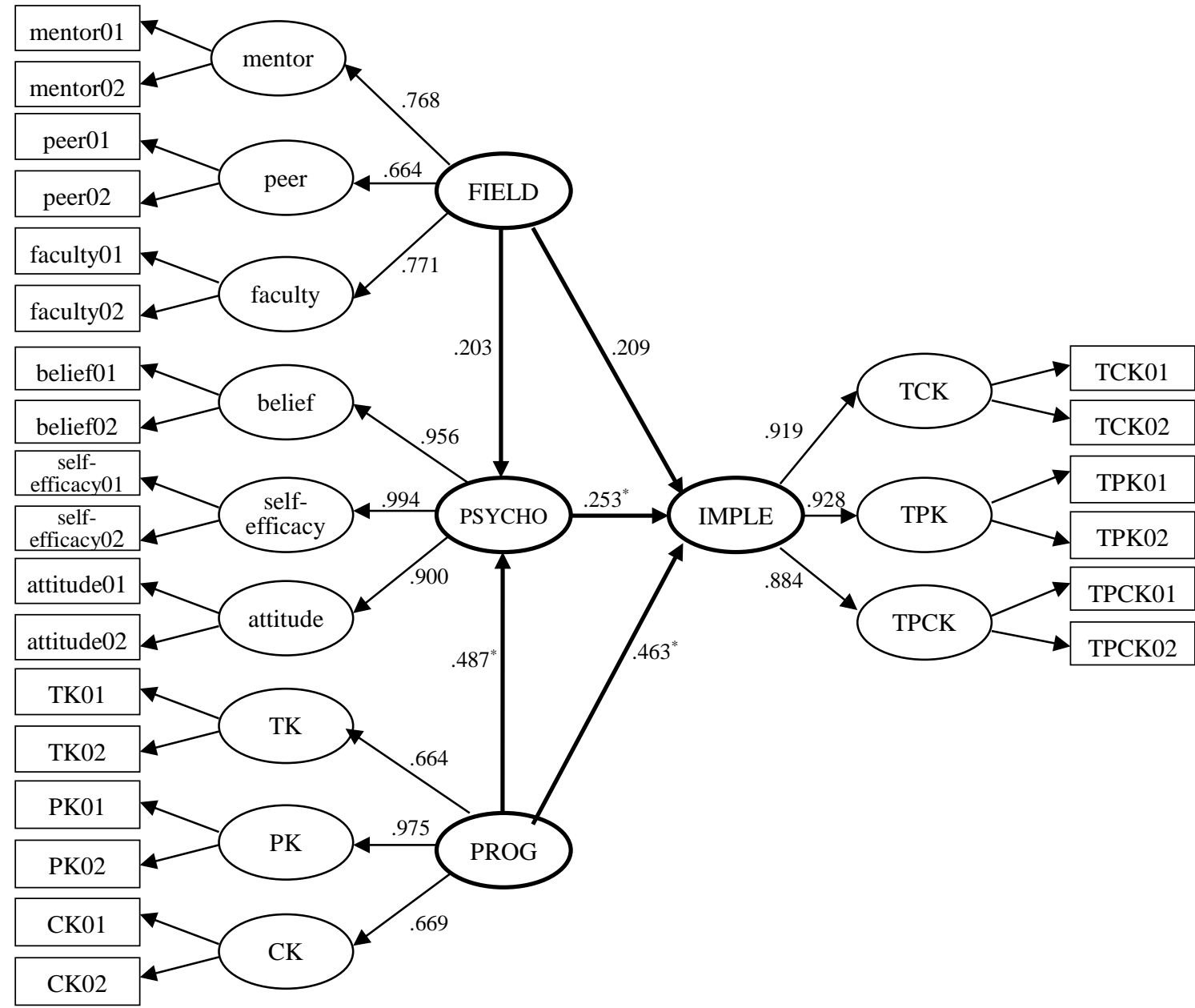

Figure 1. Path coefficients of the second-order SEM model $(p<.01)$

\section{Conclusion and discussion}

We used the SEM method to explain the relationships among four factors (teacher education programs, fieldbased experiences, psychological factors, and implementation) in technology integration for pre-service teachers. Based on literature review, each factor comprised three subfactors. This paper presents a hypothesis that the three subfactors of each factor could be reflective of one second-order latent variable; furthermore, the implementation of technology integration by pre-service teachers is explained directly or indirectly by the remaining three factors. The evaluative result exhibits an adequate fit in four second-order latent variables, and confirmed a SEM model. Furthermore, teacher education programs and psychological factors exerted a substantial and positive influence on the implementation of technology integration, whereas field-based experiences exerted only a slight influence.

Specifically, PROG substantially affected IMPLE. This finding demonstrates that pre-service teachers’ TK, $\mathrm{PK}$, and CK, acquired from teacher education programs, enabled them to use technology when teaching. FIELD revealed a minor effect on IMPLE. The interactions of pre-service teachers with mentors, peer interns, and other faculty members during field-based practicums did not lead to pre-service teachers integrating technology into instruction.

The literature review revealed that pre-service teachers can acquire the skills and methods related to technology applications from various types of technology-skills-based courses and methodology courses, in 
relation to subject matter, during teacher education courses (Anderson \& Maninger, 2007; Franklin, 2007; Kleiner et al., 2007). Our findings reveal that TK, PK, and CK acquired in teacher education programs are crucial factors in predicting pre-service teachers' implementation of technology integration. Although previous studies have suggested that coursework alone is insufficient for enabling pre-service teachers to integrate technology in teaching (Willis \& Sujo de Montes, 2002), the pre-service teachers in this study perceived that they could acquire sufficient knowledge related to technology, pedagogy, and subject content from teacher education courses (the average score of the items in TK01, PK01, and CK01 exceeds 4 and the average score of other factors). Moreover, the pre-service teachers could gain experience related to technology, pedagogy, and subject content (average score of the items in TK02, PK02, and CK02 exceeds 4 and the average score of other factors) during teacher education programs. The provided knowledge base and experience enabled the pre-service teachers to implement certain technological applications.

Furthermore, pre-service teachers in general might consider technology a useful tool for instruction, leading to positive attitudes towards technology integration and an increased willingness to use technology during teaching (Martinovic \& Zhang, 2012). Thus, teacher education programs have the most substantial influence on the implementation of technology integration, regardless of direct and indirect effects.

Our previous study (Liu, 2012) reported that teacher education courses did not substantially affect the implementation of technology integration for pre-service teachers. The survey in the previous study involved asking pre-service teachers whether teacher education courses provide them with technology integration knowledge. Because of the lack of integration of various types of teacher education courses, as reported in the literature, the assertion that teacher education courses have no effect was reasonable in the previous study. Nevertheless, the present study involved asking pre-service teachers their perceptions of TK, PK, and CK acquired from teacher education programs in the application of technology integration. With reports on the acquirement of TK, PK, and CK as well as updated views, pre-service teachers may integrate various types of knowledge to implement technology integration. In other words, the previous study focused on integrating knowledge from teacher education programs and revealed no effect, whereas the present study considered the sources of knowledge, and determined an effect on the implementation of technology integration. Therefore, the subfactors warrant consideration.

An additional finding of this study reveals that school-based field experiences exerted only a small effect on the implementation of technology integration for pre-service teachers. According to previous studies, preservice teachers have numerous opportunities to experience adequate technology practice through interactions with their mentors and faculty members (Doering et al., 2003; Rosaen et al., 2003). Relevant literature also indicates that pre-service teachers' interactions with faculty members and peers regarding technology use influence their technology integration (Le Cornu \& Ewing, 2008; Schmid, \& Hegelheimer, 2014). The learning interactions with various school faculty members might be a critical factor influencing pre-service teachers' technology integration. In this study, the pre-service teachers stated that they did not interact sufficiently with mentors, peer interns, and other faculty members before integrating technology into teaching; this finding is based on the average score (3.645) of the items in FIELD, the lowest score among all factors. Therefore, school-based field experiences exerted only a small effect on the implementation of technology integration for pre-service teachers in this study. The present study determined that the low interactions regarding technology use in instruction reduced the implementation of technology integration.

Similar to other studies (e.g., Abbitt, 2011; Anderson et al., 2011; Sang et al., 2010), this study determined that psychological characteristics involving pedagogical beliefs about, self-efficacy beliefs concerning, and attitudes towards technology integration influenced pre-service teachers' implementation of technology integration. Moreover, based on the findings of previous studies (Lambert et al., 2008; Martinovic \& Zhang, 2012; Wang et al., 2004), field-based experiences and teacher education programs can shape pre-service teachers' beliefs about, self-efficacy beliefs about, and attitudes towards technology integration. However, as asserted in this study, because of the acquirement of TK, PK, and CK, and low interactions with school personnel in field-based practicums, teacher education programs substantially affected psychological factors for pre-service teachers, whereas field-based experiences exerted no substantial effect. The psychological characteristics mediated the effects involving technology-integration activities for pre-service teachers. 
This study contributes to the literature by providing an entire model that explains the associations between pre-service teachers' implementation of technology integration and three crucial process factors: teacher education programs, field-based experiences, and personal psychological factors. On the basis of evaluating a second-order SEM, this study also provides evidence regarding the appropriateness of the subfactors to explain each crucial factor of technology integration in pre-service teachers' during teaching.

\section{Implications and limitations}

Based on the conclusion of this study, we verified the second-order SEM regarding the effects of teacher education programs, field-based practicums, psychological factors, and the subfactors regarding the implementation of technology integration for pre-service teachers. The research model can serve as a base model for future studies. Moreover, this study determined that the pre-service teachers did not interact sufficiently with mentors, peer interns, or other faculty members before integrating technology, thus showing a small effect of field-based experiences on the implementation of technology integration. By comparing the results of this study with those of previous studies regarding the effects of field-based experiences on interactions with mentors and faculty members in technology integration, future studies could investigate why pre-service teachers exhibit little interaction with school faulty and peer interns when using technology.

This study proposes that teacher education programs both directly and indirectly affect pre-service teachers' implementation of technology integration through psychological factors. However, this study could not obtain real contents of teacher education courses to identify the approaches of teacher education programs. Instead, this study relied on self-reports of pre-service teachers for various knowledge bases regarding technology integration courses. Thus, this study has one limitation: a bias may be attributable to different approaches in the consideration of teacher education programs.

\section{Acknowledgements}

The author would like to thank the Ministry of Science and Technology, Taiwan, for financially supporting this research under Contract No. NSC-102-2410-H-018-027-.

\section{References}

Abbitt, J. T. (2011). An investigation of the relationship between self-efficacy beliefs about technology integration and technological pedagogical content knowledge (TPACK) among preservice teachers. Journal of Digital Learning in Teacher Education, 27(4), 134-143. http://dx.doi.org/10.1080/21532974.2011.10784670

Abbitt, J. T., \& Klett, M. D. (2007). Identifying influences on attitudes and self-efficacy beliefs towards technology integration among preservice educators. Electronic Journal for the Integration of Technology in Education, 6(1), 28-42. Retrieved from http://ejite.isu.edu/Volume6/Abbitt.pdf

Al-Ruz, J. A., \& Khasawneh, S. (2011). Jordanian pre-service teachers' and technology integration: A human resource development approach. Educational Technology \& Society, 14(4), 77-87. Retrieved from http://www.ifets.info/journals/14_4/8.pdf

Anderson, J. C., \& Gerbing, D. W. (1988). Structural equation modeling in practice: A review and recommended two step approach. Psychological Bulletin, 103(3), 411-423. http://dx.doi.org/10.1037/0033-2909.103.3.411

Anderson, S. E., Groulx, J. G., \& Maninger, R. M. (2011). Relationships among preservice teachers’ technology-related abilities, beliefs, and intentions to use technology in their future classrooms. Journal of Educational Computing Research, 45(3), 321-338. http://dx.doi.org/10.2190/EC.45.3.d

Anderson, S. E., \& Maninger, R. M. (2007). Preservice teachers' abilities, beliefs, and intentions regarding technology integration. Journal of Educational Computing Research, 37(2), 151-172. http://dx.doi.org/10.2190/H1M8-562W-18J1-634P

Angeli, C., \& Valanides, N. (2009). Epistemological and methodological issues for the conceptualization, development, and assessment of ICT-TPCK: Advances in technological pedagogical content knowledge (TPCK). Computers \& Education, 52(1), 154-168.

http://dx.doi.org/10.1016/j.compedu.2008.07.006 
Aslan, S., Zachmeier, A., Glazewski, K., \& Ottenbreit-Leftwich, A. (2012). Technology integration concerns: A dialogue between preservice teachers and exemplary in-service Teachers. Paper presented at the annual meeting of the AECT International Convention, The Galt House, Louisville, KY. Retrieved from

$\underline{\text { http://citl.indiana.edu/files/pdf/sotl_grant_proposals/2012_sotl_proposals/glazewski_sotl_proposal_201 }}$ 2.pdf

Awotua-Efebo, E., Olele, C. N., \& Uche, C. (2014). The application of information and communication technologies in pre-service teacher education programs. International Journal of Technologies in Learning, 20(3), 27-41. Retrieved from http://ijltl.cgpublisher.com/product/pub.262/prod.63

Bollen, K. A. (1989). Structural equations with latent variables. Toronto: Wiley-Interscience.

Bollen, K. A., \& Long, S. L. (1993). Testing structural equation models. Newbury Park, CA: Sage.

Calderhead, J. (1996). Teachers: Beliefs and knowledge. In D. Berliner \& R. Calfee (Eds.), Handbook of educational psychology (pp. 709-725). New York, NY: Macmillan.

Celik, V., \& Yesilyurt, E. (2013). Attitudes to technology, perceived computer self- efficacy and computer anxiety as predictors of computer supported education. Computers \& Education, 60(1), 148-158. http://dx.doi.org/10.1016/j.compedu.2012.06.008

Chai, C. S., Koh, J. H. L., Tsai, C.-C., \& Tan, L. L. W. (2011). Modeling primary school preservice teachers' technological pedagogical content knowledge (TPACK) for meaningful learning with information and communication technology (ICT). Computers \& Education, 57(1), 1184-1193. http://dx.doi.org/10.1016/j.compedu.2011.01.007

Chen, R.-J. (2010). Investigating models for preservice teachers' use of technology to support studentcentered learning. Computers \& Education, 55(1), 32-42. http://dx.doi.org/10.1016/j.compedu.2009.11.015

Chen, Y.-L. (2008). Modeling the determinants of Internet use. Computers \& Education, 51(2), 545-558. http://dx.doi.org/10.1016/j.compedu.2007.06.007

Clausen, J. M. (2007). Beginning teachers’ technology use: First-year teacher development and the institutional context's affect on new teachers' instructional technology use with students. Journal of Research on Technology in Education, 39(3), 245-261. http://dx.doi.org/10.1080/15391523.2007.10782482

Cohen, L., Manion, L., \& Morrison, K. (2007). Research methods in education (6th). New York, NY: Routledge.

Compton, L., \& Davis, N. (2010). The impact of and key elements for a successful virtual early field experience. Contemporary Issues in Technology and Teacher Education, 10(3), 309-337. Retrieved from http://www.citejournal.org/articles/v10i3general1.pdf

Cox, S., \& Graham, C. R. (2009). Using an elaborated model of the TPACK framework to analyze and depict teacher knowledge. TechTrends, 53(5), 60-69. http://dx.doi.org/10.1007/s11528-009-0327-1

Cuckle, P., Clarke, S., \& Jenkins, I. (2000). Students’ information and communications technology skills and their use during teacher training. Journal of Information Technology for Teacher Education, 9(1), 9-22. http://dx.doi.org/10.1080/14759390000200072

Doering, A., Hughes, J., \& Huffman, D. (2003). Preservice teachers: Are we thinking with technology? Journal of Research in Education, 35(3), 342-361. http://dx.doi.org/10.1080/15391523.2003.10782390

Ertmer, P. A. (1999). Addressing first- and second-order barriers to change: Strategies for technology integration. Educational Technology Research and Development, 47(4), 47-61. http://dx.doi.org/10.1007/BF02299597

Ertmer, P. A. (2005). Teacher pedagogical beliefs: The final frontier in our quest for technology integration? Educational Technology Research and Development, 53(4), 25-39. http://dx.doi.org/10.1007/BF02504683

Finger, G., Romeo, G., Lloyd, M., Heck, D., Sweeney, T., Albion, P., \& Jamieson-Proctor, R. (2015). Developing graduate TPACK capabilities in initial teacher education programs: Insights from the teaching teachers for the future project. The Asia-Pacific Education Researcher, 24(3), 505-513. http://dx.doi.org/10.1007/s40299-014-0226-x

Fishbein, M., and Ajzen, I. (1975). Belief, attitude, intention and behaviour: An introduction to theory and research. Reading, MA: Addison-Wesley.

Franklin, C. (2007). Factors that influence elementary teachers use of computers. Journal of Technology and Teacher Education, 15(2), 267-293. Retrieved from ERIC database. (ED490605)

Gibson, S. (2012). Pre-service teachers' perspectives on learning to teach social studies in a technologyrich pedagogy course in a technology-rich pedagogy course. In P. Drew (Ed.), Developing technologyrich teacher education programs: Key issues (pp. 393-407). Hershey, PA: IGI Global. http://dx.doi.org/10.4018/978-1-4666-0014-0.ch025 
Goktas, Y., Yildirim, Z., \& Yildirim, S. (2008). A review of ICT related courses in preservice teacher education programs. Asia Pacific Education Review, 9(2), 168-179. http://dx.doi.org/10.1007/BF03026497

Hair, J. F., Anderson, R. E., Tatham, R. L., \& Black, W. C. (1998). Multivariate data analysis (5th ed.). Upper Saddle River, NJ: Prentice Hall.

Hermans, R., Tondeur, J., van Braak, J., \& Valcke, M. (2008). The impact of primary school teachers' educational beliefs on the classroom use of computers. Computers \& Education, 51(4), 1499-1509. http://dx.doi.org/10.1016/j.compedu.2008.02.001

Higgins, T. E., \& Spitulnik, M. W. (2008). Supporting teachers' use of technology in science instruction through professional development: A literature review. Journal of Science Education and Technology, 17(5), 511-521. http://dx.doi.org/10.1007/s10956-008-9118-2

Johnston, J., \& Ahtee, M. (2006). Comparing primary student teachers' attitudes, subject knowledge and pedagogical content knowledge needs in a physics activity. Teaching and Teacher Education, 22(4), 503-512. http://dx.doi.org/10.1016/j.tate.2005.11.015

Judge, S., \& O’Bannon, B. (2007). Integrating technology into field-based experiences: a model that fosters change. Computers in Human Behavior, 23(1), 286-302. http://dx.doi.org/10.1016/j.chb.2004.10.013

Kajder, S. B. (2005). Preservice English/language arts teachers'beliefs and practices in teaching with technology during the student teaching placement (Doctoral dissertation). University of Virginia, Charlottesville, VA.

Kim, C. M., Kim, M. K., Lee, C., Spector, J. M., \& DeMeester, K. (2013). Teacher beliefs and technology integration. Teaching and Teacher Education, 29, 76-85. http://dx.doi.org/10.1016/j.tate.2012.08.005

Kleiner, B., Thomas, N., \& Lewis, L. (2007). Educational technology in teacher education programs for initial licensure (NCES 2008-040). Washington, DC: National Center for Education Statistics, Institute of Education Sciences, U.S. Department of Education.

Kline, R. B. (2005). Principles and practice of structural equation modeling (2nd ed.). New York, NY: Guilford Press.

Koehler, M. J., \& Mishra, P. (2009). What is technological pedagogical content knowledge? Contemporary Issues in Technology and Teacher Education, 9(1), 60-70. Retrieved from http://www.citejournal.org/articles/v9i1general1.pdf

Lambert, J., Gong, Y., \& Cuper, P. (2008). Technology, transfer, and teaching: The impact of a single technology course on preservice teachers' computer attitudes and ability. Journal of Technology and Teacher Education, 16(4), 385-410. Retrieved from https://www.learntechlib.org/noaccess/26064

Le Cornu, R. \& Ewing, R. (2008). Reconceptualising professional experiences in preservice teacher education: Reconstructing the past to embrace the future. Teaching and Teacher Education, 24(7), 1799-1812. http://dx.doi.org/10.1016/j.tate.2008.02.008

Lee, Y., \& Lee, J. (2014). Enhancing preservice teachers’ self-efficacy beliefs for technology integration through lesson planning practice. Computers \& Education, 73, 121-128. http://dx.doi.org/10.1016/j.compedu.2014.01.001

Lim, C. P., \& Chai, C. S. (2008). Teachers’ pedagogical beliefs and their planning and conduct of computer-mediated classroom lessons. British Journal of Educational Technology, 39(5), 807-828. http://dx.doi.org/10.1111/j.1467-8535.2007.00774.x

Liu, S.-H. (2012). A multivariate model of factors influencing technology use by pre-service teachers during practice teaching. Educational Technology \& Society, 15(4), 137-149.

Llorens, S., Salanova, M., \& Grau, R. (2002). Training to technological change. Journal of Research on Technology in Education, 35(2), 206-212. http://dx.doi.org/10.1080/15391523.2002.10782380

Margaret, P., Dwight, H., \& Esther, H. (2005). Enhancing technology use in student teaching: A case study. Journal of Technology and Teacher Education, 13(4), 573-618. Retrieved from https://www.editlib.org/noaccess/4755

Martinovic, D., \& Zhang, Z. (2012). Situating ICT in the teacher education program: Overcoming challenges, fulfilling expectations. Teaching and Teacher Education, 28(3), 461-469. http://dx.doi.org/10.1016/j.tate.2011.12.001

Ministry of Education. (2013). Yearbook of teacher education statistics: The Republic of China. Taiwan: Author.

Mishra, P., \& Koehler, M. J. (2006). Technological pedagogical content knowledge: A framework for integrating technology in teacher knowledge. Teachers College Record, 108(6), 1017-1054.

http://dx.doi.org/10.1111/j.1467-9620.2006.00684.x 
Moursund, D., \& Bielefeldt, T. (1999). Will new teachers be prepared to teach in a digital age? A national survey on information technology in teacher education. Santa Monica, CA: Milken Family Foundation.

Mouza, C., Karchmer-Klein, R., Nandakumar, R., Ozden, S. Y., \& Hu, L. (2014). Investigating the impact of an integrated approach to the development of preservice teachers' technological pedagogical content knowledge (TPACK). Computers \& Education, 71, 206-221. http://dx.doi.org/10.1016/j.compedu.2013.09.020

Niederhauser, D. S., \& Perkmen, S. (2010). Beyond self-efficacy: Measuring preservice teachers’ instructional technology outcome expectations. Computers in Human Behavior, 26(3), 436-442. http://dx.doi.org/10.1016/j.chb.2009.12.002

Niess, M. L. (2005). Preparing teachers to teach science and mathematics with technology: Developing a technology pedagogical content knowledge. Teaching and Teacher Education, 21, 509-523. http://dx.doi.org/10.1016/j.tate.2005.03.006

Nokes, J. D., Bullough, R. V., Egan, W. M., Birrell, J. R., \& Hansen, J. M. (2008). The paired-placement of student teachers: An alternative to traditional placements in secondary schools. Teaching and Teacher Education, 24(8), 2168-2177. http://dx.doi.org/10.1016/j.tate.2008.05.001

Pedhazur, E. J. (1997). Multiple regressions in behavioral research (3rd). Orlando, FL: Harcourt Brace.

Polly, D., Mims, C., Shepherd, C. E., \& Inan, F. (2010). Evidence of impact: Transforming teacher education with preparing tomorrow's teachers to teach with technology (PT3) grants. Teaching and Teacher Education, 26(4), 863-870. http://dx.doi.org/10.1016/j.tate.2009.10.024

Rosaen, C. L., Hobson, S., \& Khan, G. (2003). Making connections: Collaborative approaches to preparing today's and tomorrow's teachers to use technology. Journal of Technology and Teacher Education, 11(2), 281-306. Retrieved from https://www.learntechlib.org/noaccess/14610

Russell, M., Bebell, D., O’Dwyer, L., \& O’Connor, K. (2003). Examining teacher technology use: implications for preservice and inservice teacher preparation. Journal of Teacher Education, 54(4), 297-310. http://dx.doi.org/10.1177/0022487103255985

Sadaf, A., Newby, T. J., \& Ertmer, P. A. (2012). Exploring preservice teachers’ beliefs about using Web 2.0 technologies in K-12 classroom. Computers \& Education, 59(3), 937-945. http://dx.doi.org/10.1016/j.compedu.2012.04.001

Sang, G., Valcke, M., van Braak, J., \& Tondeur, J. (2010). Student teachers’ thinking processes and ICT integration: Predictors of prospective teaching behaviors with educational technology. Computers \& Education, 54(1), 103-112. http://dx.doi.org/10.1016/j.compedu.2009.07.010

Schmid, E. C., \& Hegelheimer, V. (2014). Collaborative research projects in the technology-enhanced language classroom: Pre-service and in-service teachers exchange knowledge about technology. ReCALL, 26(3), 315-332. http://dx.doi.org/10.1017/S0958344014000135

Schmidt, D., Baran, E., Thompson, A., Mishra, P., Koehler, M., \& Shin, T. (2009). Technological pedagogical content knowledge (TPACK): The development and validation of an assessment instrument for preservice teachers. Journal of Research on Technology in Education, 42(2), 123-149. http://dx.doi.org/10.1080/15391523.2009.10782544

Schrum, L. (1999). Technology professional development for teachers. Educational Technology Research and Development, 47(4), 83-90. http://dx.doi.org/10.1007/BF02299599

Semiz, K., \& Ince, M. L. (2012). Pre-service physical education teachers' technological pedagogical content knowledge, technology integration self-efficacy and instructional technology outcome expectations. Australasian Journal of Educational Technology, 28(7), 1248-1265. http://dx.doi.org/10.14742/ajet.800

Tondeur, J., van Braak, J., Sang, G., Voogt, J., Fisser, P., \& Ottenbreit-Leftwich, A. (2012). Preparing preservice teachers to integrate technology in education: A synthesis of qualitative evidence. Computers \& Education, 59(1), 134-144. http://dx.doi.org/10.1016/j.compedu.2011.10.009

Tondeur, J., van Keer, H., van Braak, J., \& Valcke, M. (2008). ICT integration in the classroom: Challenging the potential of a school policy. Computers \& Education, 51(1), 212-223. http://dx.doi.org/10.1016/j.compedu.2007.05.003

Wang, L., Ertmer, P. A., \& Newby, T. J. (2004). Increasing preservice teachers' self-efficacy beliefs for technology integration. Journal of Research on Technology in Education, 36(3), 231-251. http://dx.doi.org/10.1080/15391523.2004.10782414

Willis, E. M., \& Sujo de Montes, L. (2002). Does requiring a technology course in preservice teacher education affect student teachers' technology use in the classroom? Journal of Computing in Teacher Education, 18(3), 76-80. http://dx.doi.org/10.1080/10402454.2002.10784439

Wu, W., Chang, H., \& Guo, C. (2008). An empirical assessment of science teachers' intentions toward technology integration. The Journal of Computers in Mathematics and Science Teaching, 27(4), 499520. Retrieved from http://www.editlib.org/p/25231/ 
Yusop, F. D. (2015). A dataset of factors that influence preservice teachers' intentions to use Web 2.0 technologies in future teaching practices. British Journal of Educational Technology. 46(5), 1075-1080. http://dx.doi.org/10.1111/bjet.12330

Corresponding author: Shih-Hsiung Liu, shsiung@cc.ncue.edu.tw

Australasian Journal of Educational Technology (c) 2016.

Please cite as: Liu, S.-H. (2016). Teacher education programs, field-based practicums, and psychological factors of the implementation of technology by pre-service teachers. Australasian Journal of Educational Technology, 32(3), 65-79. 